\title{
Intervalence charge transfer transition in mixed valence complexes synthesised from $\mathrm{Ru}^{\mathrm{III}}(\mathrm{edta})$ - and $\mathrm{Fe}^{\mathrm{II}}(\mathrm{CN})_{5}$-cores
}

\author{
H C BAJAJ, ATINDRA D SHUKLA and AMITAVA DAS* \\ Central Salt and Marine Chemicals Research Institute, Bhavnagar 364002 , \\ India \\ e-mail: salt@csir.res.in
}

\begin{abstract}
Intervalence charge transfer properties were studied for a set of mixed valence complexes incorporating $\mathrm{Ru}(\mathrm{III})$ and $\mathrm{Fe}(\mathrm{II})$-centres linked by various saturated and unsaturated bridging ligands (BL). Studies reveal that degree of ground state electronic interaction and coupling between $\mathrm{Ru}(\mathrm{III})$ and $\mathrm{Fe}$ (II)-centres can be attenuated by changing the nature of the bridging ligand. Further, inclusion of the bridging ligand with interrupted $\pi$-electron system in a $\beta$-CD cavity initiate an optical electron transfer from $\mathrm{Fe}(\mathrm{II})$ to $\mathrm{Ru}(\mathrm{III})$ which is otherwise not observed.
\end{abstract}

Keywords. Mixed valence complexes; intervalence charge transfer; rotaxane; inclusion complex; optical electron transfer; cyclodextrin.

\section{Introduction}

Experimental and theoretical study of intervalence electron transfer between two metal centres linked by a spacer group, through which electron transfer can takes place, is an area of contemporary research interest. The consequence of this process has a special relevance to inorganic reaction mechanism, biology, solid-state chemistry and the emerging field of molecular electronics ${ }^{1}$. Optical intervalence electron transfer involves transfer of an electron from a nearly localized donor site to an adjacent acceptor one, where both donor and acceptor metal ions possess more than one accessible oxidation state. There are several factors which can affect the degree of electronic coupling and thereby metal-metal interactions and electron transfer properties, of which the nature of the donor and acceptor metal ions, the bridging ligand (BL) and the surrounding environment (solvent) play a very crucial role ${ }^{2}$. Among the various metal ion systems, $\mathrm{Ru}(\mathrm{III}) / \mathrm{Ru}(\mathrm{II})$ and $\mathrm{Fe}(\mathrm{III}) / \mathrm{Fe}$ (II)-complexes have played a central role in these studies since the discovery of the Creutz-Taube ion ${ }^{3}$. In most known cases, homo $\left(\mathrm{Ru}^{\mathrm{II}}(\boldsymbol{\mu t}\right.$ $\left.\mathrm{BL}) \mathrm{Ru}^{\mathrm{III}} / \mathrm{Fe}^{\mathrm{II}}(\boldsymbol{\mu} \mathrm{BL}) \mathrm{Fe}^{\mathrm{III}}\right)$ or hetero $\left(\mathrm{Ru}^{\mathrm{II}}(\boldsymbol{\mu} \mathrm{BL}) \mathrm{Fe}^{\mathrm{III}} / \mathrm{Fe}^{\mathrm{II}}(\boldsymbol{\mu} \mathrm{BL}) \mathrm{Ru}^{\mathrm{III}}\right)$ binuclear complexes belong to valence trapped class II type or valence delocalized class III type ${ }^{4}$. $\mathrm{K}\left[\mathrm{Ru}^{\mathrm{III}}(\mathrm{edtaH}) \mathrm{Cl}\right] \cdot 2 \mathrm{H}_{2} \mathrm{O}$ and $\mathrm{Na}_{3}\left[\mathrm{Fe}^{\mathrm{II}}(\mathrm{CN})_{5}\left(\mathrm{H}_{2} \mathrm{O}\right)\right] \cdot 3 \mathrm{H}_{2} \mathrm{O}$ are attractive candidates among the different $\mathrm{Ru}(\mathrm{III})$ and $\mathrm{Fe}(\mathrm{II})$-complexes for synthesis of heterobinuclear mixed valence complexes and the study of mixed valence properties. $\mathrm{K}\left[\mathrm{Ru}{ }^{\mathrm{III}}(\mathrm{edtaH}) \mathrm{Cl}\right] \cdot 2 \mathrm{H}_{2} \mathrm{O}$ is known to exist as $\mathrm{Ru}^{\text {III }}$ (edta) $\left(\mathrm{H}_{2} \mathrm{O}\right)^{-}$in aqueous solution and to react with pyridine or substituted pyridine on the stopped flow time scale to form the corresponding pyridyl derivatives with near quantitative yield ${ }^{5} . \mathrm{Na}_{3}\left[\mathrm{Fe}^{\mathrm{II}}(\mathrm{CN})_{5}\left(\mathrm{NH}_{3}\right)\right] \cdot 3 \mathrm{H}_{2} \mathrm{O}$ also behaves analogously ${ }^{6}$. We have taken advantage of aqua substitution reaction of these two complexes to synthesize

*For correspondence 
$\mathrm{BL}$

$\mathrm{CN}^{-}$<smiles>c1cnccn1</smiles><smiles>c1cc(-c2ccncc2)ccn1</smiles><smiles>Cc1cnccc1-c1ccncc1C</smiles><smiles>C(=C/c1ccncc1)\c1ccncc1</smiles><smiles>c1cc(CCc2ccncc2)ccn1</smiles><smiles>c1cc(CCCc2ccncc2)ccn1</smiles><smiles>O=P(=O)N1C=CC(CCc2ccncc2)=CC1</smiles><smiles>O=Pc1cc(CCCc2ccncc2)ccn1</smiles><smiles>O=P(=O)N1C=CC(CCc2ccncc2)=CC1</smiles><smiles>O=[PH](=O)(O)N1C=CC(CCCc2ccncc2)=CC1</smiles>

\section{Complex}

$\mathrm{Na}_{4}\left[(\mathrm{edtaH}) \mathrm{Ru}(\mu \mathrm{NC}) \mathrm{M}(\mathrm{CN})_{5}\right]$

I $(\mathrm{M} / \mathrm{Fe})$

VIII $(M / R u)$

$\mathrm{Na} 4\left[(\right.$ edtaH $\left.) \mathrm{Ru}\left(\mu_{\text {pyz }}\right) \mathrm{Fe}(\mathrm{CN}){ }_{5}\right]$

II

$\mathrm{Na}_{4}\left[(\right.$ edtaH $) \mathrm{Ru}\left(\boldsymbol{\mu}_{\mathrm{bp}}\right) \mathrm{Fe}(\mathrm{CN})$ 5]

III

$\mathrm{Na} 4\left[(\right.$ edtaH $\left.) \mathrm{Ru}\left(\mu_{\mathrm{dmbp}}\right) \mathrm{Fe}(\mathrm{CN})_{5}\right]$

IV

$\mathrm{Na}_{4}\left[(\right.$ edtaH $) \mathrm{Ru}(\mu$-bpete $\left.) \mathrm{Fe}(\mathrm{CN})_{5}\right]$

V

$\mathrm{Na} 4\left[(\right.$ edtaH $) \mathrm{Ru}\left(\boldsymbol{\mu}\right.$-bpetae) $\left.\mathrm{Fe}(\mathrm{CN}){ }_{5}\right]$

VI

$\mathrm{Na}_{4}\left[(\mathrm{edtaH}) \mathrm{Ru}\left(\boldsymbol{\mu}\right.\right.$-bpp) $\left.\mathrm{Fe}(\mathrm{CN})_{5}\right]$

VII

$[($ edtaH)Ru(bpeta $\bullet \beta C D)]$

IX

$[($ edtaH)Ru(bpp • $\beta \mathrm{CD})]$

$\mathbf{X}$

$\mathrm{Na}_{4}\left[(\right.$ edtaH $\left.) \mathrm{Ru}\left(\boldsymbol{\mu}_{\text {bpeta }} \cdot \boldsymbol{\beta} \mathrm{CD}\right) \mathrm{Fe}(\mathrm{CN})_{5}\right] \mathbf{X I}$

$\mathrm{Na} 4\left[(\right.$ edtaH $) \mathrm{Ru}\left(\mu_{\mathrm{bpp}} \bullet \boldsymbol{\beta}_{\mathrm{CD}}\right) \mathrm{Fe}(\mathrm{CN}){ }_{5}$

XII

Figure 1. Structure of different BL, mono- and binuclear mixed valence complexes. 
a set of mixed valence hetero binuclear complexes of the type $\mathrm{Na}_{3+x}\left[\mathrm{Ru}(\mathrm{edtaH})(\boldsymbol{\mu} \mathrm{BL})^{x-}\right.$ $\mathrm{Fe}(\mathrm{CN})_{5}$ ] (figure 1), where $\mathrm{BL}$ is $\mathrm{CN}^{-}$, pyrazine (pyz), 4,4'-bipyridine (bp), 3,3'-dimethyl4,4'-bipyridine (dmbp), trans-1,2-bis-(4-pyridyl)ethylene (bpete), 1,2-bis(-4-pyridyl) ethane (bpeta) and 1,3-bis-(4-pyridyl)propane (bpp). The main aim of our studies is to address the role of length, conjugation and conformation of the BL on metal-metal interaction and thus on the mixed valence properties. Further, Macartney and his coworkers have successfully demonstrated the in-situ formation of semirotaxane and [2]rotaxane complexes through reverse aquation of labile $\mathrm{Fe}^{\mathrm{II}}$-py bond in homobinuclear complexes with general formula $\left[(\mathrm{CN})_{5} \mathrm{Fe}^{\mathrm{II}}(\boldsymbol{\mu} \mathrm{BL}) \mathrm{Fe}^{\mathrm{II}}(\mathrm{CN})\right]^{6-}$ and the subsequent self assembly of $\mathrm{BL}$ of the mononuclear component $\left[\mathrm{Fe}^{\mathrm{II}}(\mathrm{CN})_{5} \mathrm{BL}\right]^{3-}$, in $\beta \mathrm{CD}$ cavity ${ }^{7}$. This particular observation prompted us to investigate the possibility of synthesizing mixed valence [2]rotaxane complexes of the type $\left[(\text { edta }) \mathrm{Ru}^{\mathrm{III}}(\boldsymbol{\mu} \mathrm{BL} \bullet \boldsymbol{\beta C D}) \mathrm{Fe}^{\mathrm{II}}(\mathrm{CN})_{5}\right]^{4-}$, which has enabled us to study the effect of inclusion of BL in hydrophobic $\beta$ CD cavity. This present article is a brief overview of the intervalence charge transfer properties of a set of mixed valence complexes, synthesized using $\mathrm{Ru}^{\mathrm{III}}\left(\mathrm{edta}^{-} / \mathrm{Fe}^{\mathrm{II}}(\mathrm{CN})_{5}^{3-}\right.$ centres and the role of inclusion of BL in $\beta$-CD cavity on intervalence charge transfer (IVCT) transitions.

\section{Synthesis}

Procedures for synthesis of various ligands, mono- and bi-nuclear complexes (I-VIII) are described in earlier reports ${ }^{8-13}$. Here we have described briefly the synthetic methodology for semirotaxane (IX, X) and [2] rotaxane complexes (XI, XII).

\section{$2.1 \quad[\mathrm{Na}(\mathrm{edta}) \mathrm{RuBL} \bullet \boldsymbol{\beta} \mathrm{CD}] \cdot 2 \mathrm{H}_{2} \mathrm{O}\{\mathrm{BL}:$ bpeta $(\boldsymbol{I X})$ and $\operatorname{bpp}(\boldsymbol{X})\}$}

The pre-synthesized complex, (edtaH)Ru(bpeta) $\left(0.2 \mathrm{~g}, 3.5 \times 10^{-4} \mathrm{~mol}\right)$ was stirred with $\beta$-CD $\left(0.48 \mathrm{~g}, 4.2 \times 10^{-4} \mathrm{~mol}\right)$ in $25 \mathrm{ml}$ water for $30 \mathrm{~min}$ at room temperature. Then volume of the reaction mixture was reduced to about $2 \mathrm{ml}$ and by adding excess acetone the desired product was precipitated out. It was recrystallised twice from water-methanol mixture to get pure complex IX. Analytical studies clearly show the formation of semirotaxane complex IX. Yield: $0.39 \mathrm{~g}(65 \%)$; FAB mass: $1710\left(\mathrm{M}^{+}\right)$; Elemental analysis: (expt.) C 44.1, H 5.7, N 3.2\%; (calc. with $2 \mathrm{H}_{2} \mathrm{O}$ ) C 44.9, H 5.55, N 3.28\%; UV-Vis $\left(\mathrm{H}_{2} \mathrm{O}\right): 269 \mathrm{~nm}$ (sh), IR ( $\mathrm{KBr}$ similar): $3402(b r), 1658,1642, E_{1 / 2}\left(\mathrm{Ru}^{\mathrm{III} / \mathrm{II}}\right)$ : $-0 \cdot 35 \mathrm{~V}(190 \mathrm{mV})$.

Complex $\mathbf{X}$ was synthesized following similar procedure using (edtaH)Ru(bpp) as starting complex. Yield: 0.36 g (60\%); FAB mass: $1722\left(M^{+}\right)$; Elemental analysis: (expt) C 43.6, H 5.6, N 3.2\%; (calc. with $2 \mathrm{H}_{2} \mathrm{O}$ ) C 44.7, H 5.6, N 3.28\%; UV-Vis $\left(\mathrm{H}_{2} \mathrm{O}\right)$ : $270 \mathrm{~nm}(\mathrm{sh}), \mathrm{IR}\left(\mathrm{KBr}, \mathrm{cm}^{-1}\right): 3382(b r), 1654,1639, E_{1 / 2}\left(\mathrm{Ru}^{\mathrm{III} / \mathrm{II}}\right):-0 \cdot 36 \mathrm{~V}(185 \mathrm{mV})$.

\section{$2.2\left[\mathrm{Na}_{4}(\mathrm{edta}) \mathrm{Ru}\left(\boldsymbol{\mu} \mathrm{BL} \bullet \boldsymbol{\beta}-\mathrm{CDFe}(\mathrm{CN})_{5}\right] \cdot 2 \mathrm{H}_{2} \mathrm{O}\{\mathrm{BL}:\right.$ bpeta; $(\boldsymbol{X I})$ and bpp $(\boldsymbol{X I I})\}$}

$210 \mathrm{mg}\left(1.23 \times 10^{-4} \mathrm{~mol}\right)$ of complex IX and $0.110 \mathrm{~g}\left(1.0 \times 10^{-4} \mathrm{~mol}\right)$ of $\beta$ CD were dissolved in $20 \mathrm{ml}$ water to which $\mathrm{Na}_{3}\left[\mathrm{Fe}(\mathrm{CN})_{5} \mathrm{NH}_{3}\right] \cdot 2 \mathrm{H}_{2} \mathrm{O}\left(40 \mathrm{mg}, 1.5 \times 10^{-4} \mathrm{~mol}\right)$ was added and stirred at RT for one hour. The colour of the solution slowly changes to pale blue. Volume of the resulting mixture was reduced to $2 \mathrm{ml}$ by fridge drying method and excess acetone was added to precipitate complex XI. Complex was washed thoroughly with methanol and further purified by recrystallization from water-methanol mixture. Yield: $0.14 \mathrm{~g}$ (57\%), ESMS mass: $1963\left(M^{+}\right)$; Elemental analysis: (expt) C 41.0, H 4.9, 
$\mathrm{N} 6.2 \%$; (calc. with $\left.2 \mathrm{H}_{2} \mathrm{O}\right) \mathrm{C} 41.7, \mathrm{H} 4.8, \mathrm{~N}$ 6.34\%; UV-Vis -N/R $\left(\varepsilon ; \mathrm{H}_{2} \mathrm{O}\right): 296$ $\left(7.3 \times 10^{3}\right), 352\left(5 \cdot 3 \times 10^{3}\right)$ and $998\left(1.46 \times 10^{3}\right) ; \mathrm{IR}\left(\mathrm{KBr}, \mathrm{cm}^{-1}\right): 3046(\mathrm{br}), 2061,1657$ and $1633 ; E_{1 / 2}\left(\mathrm{Ru}^{\mathrm{III} / \mathrm{II}}\right):-0.35$ and $E_{1 / 2}\left(\mathrm{Fe}^{\mathrm{III} / \mathrm{II}}\right)-0 \cdot 015 \mathrm{~V}$.

For complex XII synthetic procedure is same as $\mathbf{X I}$; complex $\mathbf{X}(0.21 \mathrm{~g}, 1.23 \times$ $\left.10^{-4} \mathrm{~mol}\right)$ was used instead of complex IX. Yield: $0 \cdot 13 \mathrm{~g}(53 \%)$, ESMS mass: $1977\left(M^{+}\right)$, Elemental analysis: (expt) $\mathrm{C} 41.2, \mathrm{H} 4.9, \mathrm{~N} 6.2 \%$; (calc. with $0.07 \beta \mathrm{CD}$ and $2 \mathrm{H}_{2} \mathrm{O}$ ) $\mathrm{C} 42.0, \mathrm{H} 4.85, \mathrm{~N} 6.3 \%$, UV-Vis $\left(\varepsilon ; \mathrm{H}_{2} \mathrm{O}\right): 300\left(2.4 \times 10^{3}\right), 356\left(1.6 \times 10^{3}\right)$ and 985 $\left(1.36 \times 10^{3}\right), \mathrm{IR}\left(\mathrm{KBr}, \mathrm{cm}^{-1}\right): 3378(b r), 2057,1652$ and $1629 ; E_{1 / 2}\left(\mathrm{Ru}^{\mathrm{III} / \mathrm{II}}\right):-0.36$ and $E_{1 / 2}$ $\left(\mathrm{Fe}^{\mathrm{III} / \mathrm{II}}\right)-0 \cdot 01 \mathrm{~V}$.

\section{Results and discussion}

Mononuclear complexes [(edtaH)Ru $\left.{ }^{\text {III }}(\mathrm{BL})\right]$ and mixed valence bi-nuclear complexes $\left[(\mathrm{edtaH}) \mathrm{Ru}^{\mathrm{III}}(\boldsymbol{\mu} \mathrm{BL}) \mathrm{Fe}^{\mathrm{II}}(\mathrm{CN})_{5}\right]^{4-}$ were synthesized by taking the advantage of the facile aqua substitution reaction of $\mathrm{Ru}($ edta $)\left(\mathrm{H}_{2} \mathrm{O}\right)^{-}$and $\mathrm{Fe}(\mathrm{CN})_{5}\left(\mathrm{H}_{2} \mathrm{O}\right)^{3-}$ with substituted pyridine based bidentate ligands. Mononuclear complexes, (edtaH) $\mathrm{Ru}^{\mathrm{III}}(\mathrm{BL})$, having a pendant pyridine group, are used as ligand for reaction with $\mathrm{Fe}(\mathrm{CN})_{5}\left(\mathrm{H}_{2} \mathrm{O}\right)^{3-}$ for the synthesis of binuclear complexes. All binuclear complexes were isolated and characterized by standard analytical and spectroscopic techniques. Kinetic parameters for the formation of these complexes are summarized in table 1 . Further 4,4'-bipyridine (bp) and its derivatives are known to form labile inclusion complexes with $\alpha$ and $\beta$ Cyclodextrine (CD) in aqueous solution. Macartney and his coworkers have established

Table 1a. Rate constants and activation parameters for aqua substitution reactions.

\begin{tabular}{|c|c|c|c|c|}
\hline \multirow[b]{2}{*}{ BL } & \multicolumn{2}{|c|}{ Scheme 1} & \multirow{2}{*}{$\begin{array}{l}\text { Scheme } 2 \\
10^{2} k_{d}\left(\mathrm{~s}^{-1}\right)\end{array}$} & \multirow{2}{*}{$\begin{array}{c}\text { Eq. } 2 \\
10^{3} k_{d}^{\text {dmso }}\left(\mathrm{s}^{-1}\right)\end{array}$} \\
\hline & $k_{f}\left(\mathrm{M}^{-1} \mathrm{~s}^{-1}\right)$ & $10^{4} k_{d}^{\mathrm{CD}}$ & & \\
\hline bpeta & $9 \cdot 0$ & $8 \pm 3$ & $4 \cdot 0$ & $1 \cdot 2(40)^{\mathrm{a}}$ \\
\hline bpp & $16 \cdot 5$ & $9 \cdot 8 \pm 4$ & 4.9 & $9 \cdot 4(40)^{\mathrm{a}}$ \\
\hline bpeta $\Delta H^{\#}\left(\mathrm{kJmol}^{-1}\right)$ & $38 \pm 3$ & - & $65 \cdot 8 \pm 2$ & $72 \pm 2$ \\
\hline$\Delta S^{\#}\left(\mathrm{JK}^{-1} \mathrm{~mol}^{-1}\right)$ & -80 & - & $-6 \pm 6$ & $-1 \pm 3$ \\
\hline bpp $\Delta H^{\#}\left(\mathrm{kJmol}^{-1}\right)$ & $22 \pm 2 \cdot 8$ & - & $72 \cdot 4 \pm 3$ & $85 \pm 3$ \\
\hline$\Delta S^{\#}\left(\mathrm{JK}^{-1} \mathrm{~mol}^{-1}\right)$ & -110 & - & $-7 \pm 8$ & $10 \pm 9$ \\
\hline
\end{tabular}

$k_{f}$ and $k_{d}$ values were evaluated from kinetic studies performed at $25^{\circ} \mathrm{C}$, unless

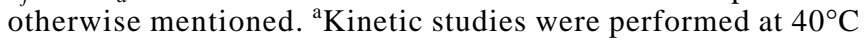

Table 1b. Rate constants ${ }^{7 \mathrm{e}}$ and forward and reverse aquation for the reaction.

\begin{tabular}{lcc}
{$\left[\mathrm{Fe}(\mathrm{CN})_{5}\left(\mathrm{H}_{2} \mathrm{O}\right)\right]^{3-}+\mathrm{BL} \bullet \beta-\mathrm{CD}$} & $\sum_{\substack{k-\mathrm{CD} \\
k-\mathrm{CD}}}^{\beta-\mathrm{CD}}\left[\mathrm{Fe}(\mathrm{CN})_{5}(\mathrm{BL} \bullet \beta-\mathrm{CD})\right]^{3-}+\mathrm{H}_{2} \mathrm{O}$ \\
\hline $\mathrm{L}$ & $k_{f m}^{\beta-\mathrm{CD}}\left(\mathrm{M}^{-1} \mathrm{~s}^{-1}\right)$ & $k_{b m}^{\beta-\mathrm{CD}}\left(\mathrm{M}^{-1} \mathrm{~s}^{-1}\right)$ \\
\hline bp & $703 \pm 11$ & $72 \pm 44$ \\
bpete & $757 \pm 19$ & $134 \pm 11$ \\
bpeta & $727 \pm 85$ & $87 \pm 4$ \\
bpp & $717 \pm 19$ & $116 \pm 76$ \\
\hline
\end{tabular}


Table 1c. Rate constants ${ }^{11,12}$ for forward and reverse aquation for the reaction:

$\left.\left[\mathrm{Fe}(\mathrm{CN})_{5}\left(\mathrm{H}_{2} \mathrm{O}\right)\right]^{3-}+(\mathrm{edta}) \mathrm{RuBL}\right]^{-} k_{f} \square \square k_{b}\left[\mathrm{Fe}(\mathrm{CN})_{5}(\mu \mathrm{BL}) \mathrm{Ru}(\mathrm{edta})\right]^{4-}+\mathrm{H}_{2} \mathrm{O}$

\begin{tabular}{lcc}
\hline $\mathrm{L}$ & $k_{f}\left(\mathrm{M}^{-1} \mathrm{~s}^{-1}\right)$ & $k_{b}\left(10^{3}\right)\left(\mathrm{s}^{-1}\right)$ \\
\hline pyz & $150 \pm 10$ & $2 \pm 0 \cdot 6$ \\
bp & $175 \pm 15$ & $20 \pm 20$ \\
dmbp & $146 \pm 10$ & $35 \pm 10$ \\
bpete & $684 \pm 35$ & $9 \pm 5$ \\
bpp & $154 \pm 10$ & $154 \pm 20$ \\
\hline
\end{tabular}

the formation of these inclusion complexes based on the complexation induced shift in the proton resonance for both the host ( $\alpha$ and $\beta-C D)$ and guest (bp and its derivatives) molecules ${ }^{7,14}$ and studied their formation kinetics. bp and its derivatives, thus included in the CD-cavity, are known to react with $\left[\mathrm{Fe}(\mathrm{CN})_{5}\left(\mathrm{H}_{2} \mathrm{O}\right)\right]^{3-}$ to form the corresponding $\left[\mathrm{Fe}(\mathrm{CN})_{5}(\mathrm{BL} \cdot \beta-\mathrm{CD}]^{3-}\right.$ complexes with a rate constant which is much lower than that involving non-included bp derivatives (table 1). Kinetics of the formation of homobinuclear complexes $\left(\left[\left\{\mathrm{Fe}(\mathrm{CN})_{5}\right\}_{2}(\boldsymbol{\mu} \mathrm{BL} \bullet \beta-\mathrm{CD})\right]^{6-}\right)$ by reacting semirotaxane complexes, in presence of large excess of $\beta-C D$, with another molecule of $\left[\mathrm{Fe}(\mathrm{CN})_{5}\left(\mathrm{H}_{2} \mathrm{O}\right)\right]^{3-}$ was also studied ${ }^{7}$. All these studies were performed in solution phase. However, no such semirotaxane and [2] rotaxane complexes were isolated following this methodology. We have used the promiscuous binding property of $\beta \mathrm{CD}$ towards the $\mathrm{bp}$ and its derivatives for the preparation of inclusion complex (BL• $\beta-C D)$ in solution, which was allowed to react with $\left[\mathrm{Ru}(\text { edta }) \mathrm{H}_{2} \mathrm{O}\right]^{-}$at $p \mathrm{H} \sim 5$ to form the corresponding semirotaxane complexes $\left([\mathrm{Ru}(\mathrm{edta})(\mathrm{BL} \bullet \beta \mathrm{CD})]^{-}\right)$and were isolated as Na-salts ${ }^{13}$. These semirotaxane complexes were used as ligands for further reaction with $\mathrm{Fe}(\mathrm{CN})_{5}\left(\mathrm{H}_{2} \mathrm{O}\right)^{3-}$ for the synthesis of the [2]rotaxane complexes. Kinetics for the formation of the [2]rotaxane complexes $\left(1 ; \mathrm{L}\right.$ is edta $\left.{ }^{4-}\right)$ follow the rate law (2) similar to that of the noninclusion complexes ${ }^{5,8-12,15}$.

$$
\begin{gathered}
{[\mathrm{LRu}(\mathrm{BL} \bullet \beta-\mathrm{CD})]^{-}+\left[\mathrm{Fe}(\mathrm{CN})_{5}\left(\mathrm{H}_{2} \mathrm{O}\right)\right]^{4-} \prod_{b}^{\beta-\mathrm{CD}}} \\
{\left[\mathrm{Fe}(\mathrm{CN})_{5}(\mathrm{BL} \bullet \beta-\mathrm{CD}) \mathrm{Ru}(\mathrm{edta})\right]^{4-}+\mathrm{H}_{2} \mathrm{O}} \\
k_{\mathrm{obs}}=k_{f}^{\beta-\mathrm{CD}}\left[\left\{(\text { edta }) \operatorname{RuBL} \bullet \beta-\mathrm{CD}^{-}\right\}\right]+k_{b}^{\beta-\mathrm{CD}} .
\end{gathered}
$$

Small but definite reverse aquation reaction (reverse rate constant, $k_{d}^{\beta-\mathrm{CD}}$ ) is observed; though value for this is found to be lower (table 1) than that observed for $\left[\left\{(\text { edta }) \mathrm{Ru}(\mathrm{bpp}) \mathrm{Fe}(\mathrm{CN})_{5}\right\}\right]^{4-}$ and related complexes ${ }^{8-15,16}$. The net decrease in the rate constant for forward reaction $\left(k_{f}\right)$ is presumably due to enhanced steric and electronic hindrance that result from the $\beta$-CD inclusion of the heterocyclic spacer group.

[2]rotaxane complexes (XI and XII) can also be synthesized in situ by utilizing the reverse aquation of pre-synthesized binuclear complexes VI and VII in presence of known amount of excess $\beta-C D$, adopting self-assembly route (scheme 1). Kinetics for the 

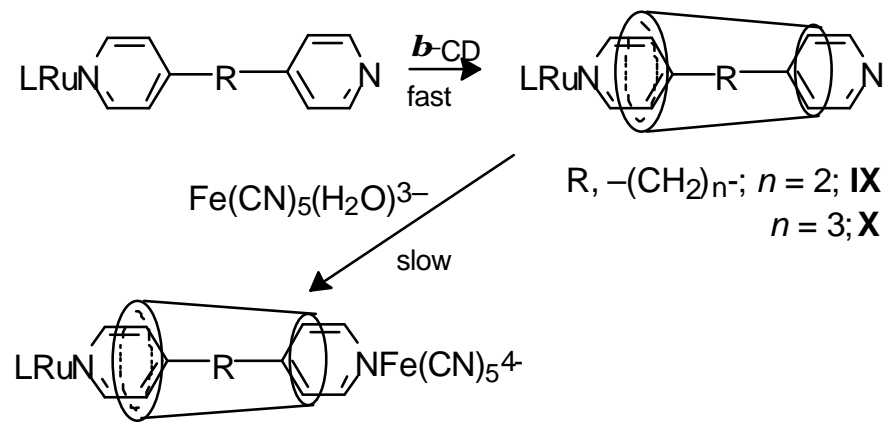

$$
\begin{array}{r}
\mathrm{R},-\left(\mathrm{CH}_{2}\right) n^{-} ; n=2 ; \mathbf{X I} \\
n=3 ; \mathbf{X I I}
\end{array}
$$

\section{Scheme 1.}
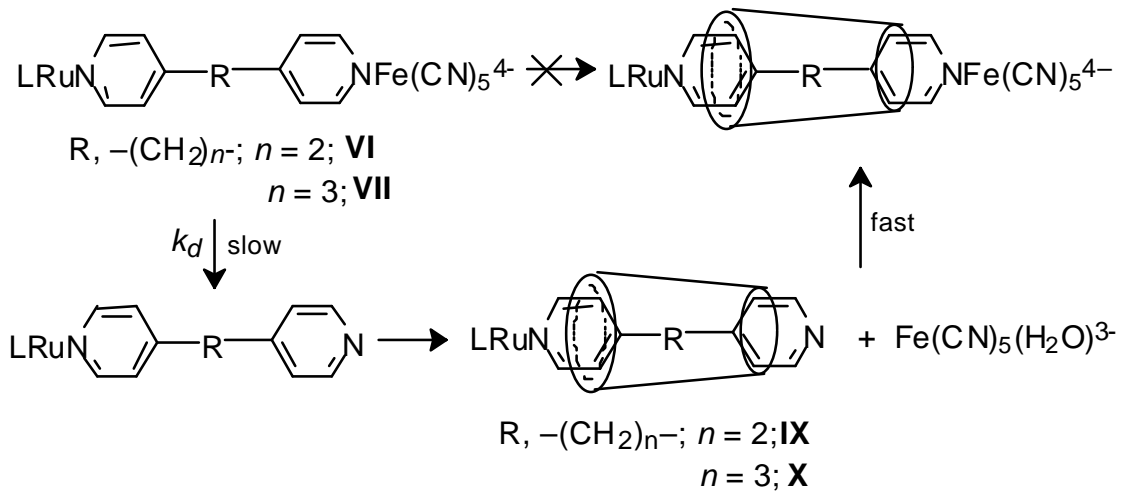

Scheme 2.

[2]rotaxane formation following the self assembly route is monitored by growth in absorbance at $1000 \mathrm{~nm}$ (figure 2) ${ }^{17}$. Detailed kinetic studies show that the rate determining step is the slow dissociation of Fe-pyridine bond in $[\{($ edta $) \mathrm{Ru}(\boldsymbol{\mu} t$ bpp) $\left.\left.\mathrm{Fe}(\mathrm{CN})_{5}\right\}\right]^{4-}$ complex, which has also been confirmed by its reaction with DMSO (vide infra).

On addition of excess DMSO to the aqueous solution of [2] rotaxane complexes, XI and XII, gradual bleaching of the NIR band with time was registered. DMSO reacts with $\left[\mathrm{Fe}(\mathrm{CN})_{5}\left(\mathrm{H}_{2} \mathrm{O}\right)\right]^{3-}$, produced through the dissociation of $\mathrm{Fe}^{\mathrm{II}}$-py bond in complexes $\mathbf{X I}$ and XII, to form a kinetically inert complex $\left[\mathrm{Fe}(\mathrm{CN})_{5}(\mathrm{DMSO})\right]^{3-}\left(3, \mathrm{~L}\right.$ is $\mathrm{L}$ is edta $\left.{ }^{4-}\right)$ and thereby prevent further binuclear complex formation. Kinetics of decomposition of [2]rotaxane (complexes XI and XII) in presence of excess DMSO and $\beta$ CD is studied at $1000 \mathrm{~nm}^{18}$. The observed first order dissociation rate constant $\left(k_{d}^{\mathrm{DMSO}}\right)$ and activation parameters are summarized in table 1 , which reveal that dissociation rate constant decreases significantly upon inclusion of ligand in $\beta C D$ cavity. This further demonstrates that $\beta$-CD inclusion of the BL enhances the stability of binuclear complexes towards aquation reaction of the $\mathrm{Fe}^{\mathrm{II}}$-py centre. 


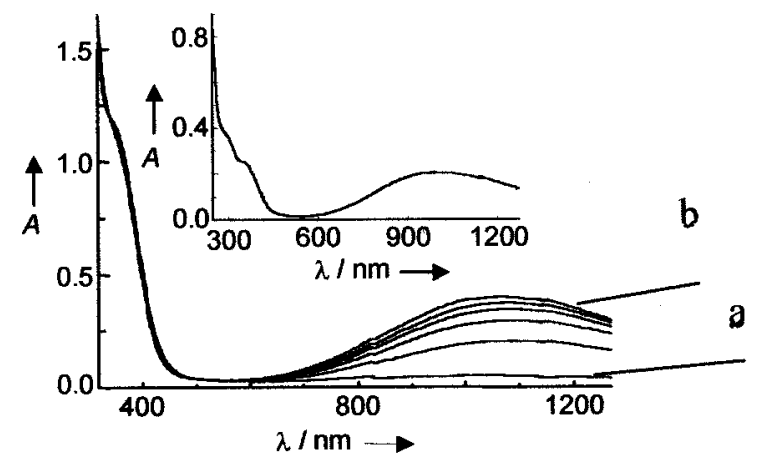

Figure 2. $1 \mathrm{ml}$ of $3.5 \times 10^{-3} \mathrm{M} \quad\left[\left(\right.\right.$ edta)Ru(bpp)], $0.1 \mathrm{ml}$ of $3.5 \times 10^{-4} \mathrm{M}$ $\mathrm{Fe}(\mathrm{CN})_{5}\left(\mathrm{H}_{2} \mathrm{O}\right)^{3-}, \mu=0 \cdot 1 \mathrm{M}(\mathrm{KCl})$ and then kept in dark of $15 \mathrm{mt}$ at $p \mathrm{H} \mathrm{5 \cdot 0.} \mathrm{To} \mathrm{this}$ $1.2 \mathrm{ml}$ of $1.6 \times 10^{-2} \mathrm{M} \beta-\mathrm{CD}$ was added and electronic spectra were recorded at different time intervals, keeping reaction temperature at $35^{\circ} \mathrm{C}$. Time interval, between the initial (a) and final (b) spectra recorded, was 90 m. Inset: Absorption spectra for $1.5 \times 10^{-4} \mathrm{M}$ of isolated complex XII in water.

$$
\left[\mathrm{LRu}(\boldsymbol{\mu}-\mathrm{BL} \bullet \boldsymbol{\beta}-\mathrm{CD}) \mathrm{Fe}(\mathrm{CN})_{5}\right]^{4-} \underset{\mathrm{DMSO}}{\stackrel{\beta-\mathrm{CD}}{\longrightarrow}}[\mathrm{LRu}(\mathrm{BL} \bullet \boldsymbol{\beta}-\mathrm{CD})]^{-}+\left[\mathrm{Fe}(\mathrm{CN})_{5} \mathrm{DMSO}\right]^{3-}
$$

\section{Intervalence electron transfer}

Cyanide and other N-based heterocyclic binucleating ligands are used in our laboratory to synthesize and isolate a set of new hetero binuclear mixed valence complexes with general formula $\mathrm{Na}_{(3+x)}\left[\mathrm{Ru}^{\mathrm{III}}(\mathrm{edtaH})(\mu \mathrm{BL})^{(x-)} \mathrm{Fe}^{\mathrm{II}}(\mathrm{CN})_{5}\right]$ where $\mathrm{BL}$ is $\mathrm{CN}^{-}$, bp, dmbp, bpete, bpeta, bpp (figure 1). Electronic spectra for these complexes are basically the summation of the electronic spectra of individual components i.e. $\mathrm{Ru}^{\text {III }}$ (edta)(py) $)^{-}$and $\mathrm{Fe}^{\mathrm{II}}(\mathrm{CN})_{5}(\mathrm{py})^{3-}$ cores along with a broad absorption band in the region $900<\lambda$ $<1000 \mathrm{~nm}$. This broad band is not observed in the complexes VI and VII. Further, the NIR band for I-V and VIII disappear either on electrochemical reduction of Ru(III) centre at $\sim-0.3 \mathrm{~V}$ (vs SCE) or on oxidation of Fe(II) centre at $\sim 0.6 \mathrm{~V}$ (vs SCE) and is assigned as the intervalence charge transfer transition band (IVCT) for optical electron transfer from $\mathrm{Fe}(\mathrm{II})$ to $\mathrm{Ru}(\mathrm{III})$ (4). $\varepsilon$ values observed for the IVCT band of these complexes are comparable with the related mixed valence complexes ${ }^{19}$. Experimentally obtained values for wave number $(v)$, molar absorbance at $\lambda_{\mathrm{IVCT}}(\varepsilon)$ and bandwidth at the half maxima $\left(\Delta \mathbf{v}_{1 / 2}\right)$ for the intervalence charge transfer band for complexes $\mathbf{I}-\mathbf{V}$ and $\mathbf{V I I I}$ are present in table 2. Assuming, compounds I-V and VIII belong to Robin-Day class II type and from a Gausian band shape, a lower limit for the bandwidth $\left(\Delta \mathbf{v}_{1 / 2}\right)$ at room temperature can be calculated ${ }^{3,20}$ from equation 5 and the values are presented in table 2 .

$$
\begin{aligned}
& {\left[\left(\text { edtaH)Ru }{ }^{\mathrm{III}}-\mathrm{BL}-\mathrm{Fe}^{\mathrm{II}}(\mathrm{CN})_{5}\right]^{3-} \bigsqcup_{n_{n}^{\mathrm{p}}}^{\mathrm{p}}\left[[\mathrm{edtaH}) \mathrm{Ru}^{\mathrm{II}}-\mathrm{BL}-\mathrm{Fe}^{\mathrm{III}}(\mathrm{CN})_{5}\right]^{3-}\right. \text {, }} \\
& \Delta \mathbf{V}_{1 / 2}=\left(2310 \mathrm{~V}_{\max }\right)^{1 / 2},
\end{aligned}
$$


$\Delta \mathbf{v}_{1 / 2}$ values allow us to calculate values for ground state delocalisation $\left(\alpha^{2}\right)$ and the measure of electronic coupling $\left(H_{\mathrm{AB}}\right)$ based on the following relations $(6$ and 7$)$ and are summarized in table 2 .

$$
\begin{aligned}
& \alpha^{2}=4.24 \times 10^{-4} \varepsilon_{\max } \Delta v_{1 / 2} / \nu_{\max } r^{2}, \\
& H_{\mathrm{AB}}=\left(2.05 \times 10^{-2} r\right) \varepsilon_{\max },
\end{aligned}
$$

( $r$ is the separation between donor-acceptor wave function).

The reproducibility of $\Delta \mathrm{V}_{1 / 2}$ values obtained experimentally and calculated on the basis of Marcus-Hush theory (5) supports the validity of the description of these complexes as weakly coupled valence trapped system. Further, the delocalisation parameter $(\boldsymbol{\alpha})$ should be less than $0 \cdot 25$ for the mixed valence compounds to be considered as class II - which is the case for complexes $\mathbf{I}-\mathbf{V}$ and VIII and thus indicates that the valences of the metal centres can be considered as essentially trapped ${ }^{21}$. Values of $\alpha^{2}$ and $H_{\mathrm{AB}}$, presented in table 2, reveal that an increase in length of the spacer group, which links the two metal centres, attenuates the communication between them. The plot of $2 \ln H_{\mathrm{AB}}$ vs $r$ (figure 3 ) gives a straight line with $\beta=0 \cdot 26 \AA^{-1}$, which reveals the measure of attenuation of electronic overlap of donor and acceptor with the bridge and is close to that reported for polyene-bridged ruthenium amine complexes $\left(0 \cdot 22 \AA^{-1}\right)^{22}$.

For complexes having low lying $\pi^{{ }^{*}}{ }_{\mathrm{BL}}$ orbitals, electron transfer between the two metal centres occurs through the LUMO of BL. Thus, metal-metal interaction is expected to depend on the energy gap between $d_{\pi}\left(M_{1}\right)$ or $d_{\pi}\left(M_{2}\right)$ and $\pi^{*}$ (LUMO) of BL orbital. Further, double coordination of BL lowers the $\pi^{*}{ }_{B L}$ orbital, such that each binding site may couple more efficiently with individual metal core. The observed trend i.e., the decrease in metal-metal interaction with increase in the distance that separates them matches with theoretical prediction on the basis of MO calculations ${ }^{22,23}$. For complex VIII, $\left.\mathrm{Na}_{4}[(\mathrm{edtaH}) \mathrm{Ru}(\boldsymbol{\mu} \mathrm{NC}) \mathrm{RuCN})_{5}\right]$, the more positive $E_{1 / 2}$ value for the $\mathrm{Ru}(\mathrm{II}) /(\mathrm{III})$ couple $(0.67 \mathrm{~V}$ vs $\mathrm{SCE})$ for $\mathrm{Ru}(\mathrm{CN})_{6}^{4-}$ component compared to $\mathrm{Fe}(\mathrm{II}) /(\mathrm{III})$ couple $(0.23 \mathrm{~V}$ vs $\mathrm{SCE})$ for $\mathrm{FeCN})_{6}^{4-}$ component in complex $\mathbf{I}$ results a larger difference in ground state redox potentials of the two metal centres in VIII. The difference in energies of the IVCT bands (table 2) for complexes I and VIII is $0.44 \mathrm{eV}$, which basically is the reflection of the difference in two redox potentials $\left(E_{\mathrm{op}}\left[\mathrm{Ru}^{\mathrm{III}}-\mathrm{Ru}^{\mathrm{II}}\right]_{\mathrm{VIII}}-E_{\mathrm{op}}\left[\mathrm{Ru}^{\mathrm{III}}-\right.\right.$ $\left.\left.\mathrm{Fe}^{\mathrm{II}}\right]_{\mathrm{I}}=\Delta E_{\mathrm{op}} \quad(0.50 \mathrm{eV})=\Delta\left[\Delta E_{\mathrm{I} / 2}\right]\right)^{24}$. For complexes, VI and VII, there exist an interrupted $\pi$ electron system and thus no orbital pathway is available for metal-metal

\begin{tabular}{|c|c|c|c|c|c|c|c|}
\hline \multirow[b]{2}{*}{ Parameters } & \multicolumn{7}{|c|}{ BL } \\
\hline & $\mathrm{CN}^{-}$ & Pyz & $\mathrm{bp}$ & $\mathrm{dmbp}$ & bpete & bpeta $\bullet \beta-C D$ & $\mathrm{bpp} \bullet \beta-\mathrm{CD}$ \\
\hline$v_{\max }\left(\mathrm{cm}^{-1}\right)$ & 10,638 & 10,917 & 10,718 & 10,163 & 10,030 & 10,020 & 10,152 \\
\hline $\begin{array}{c}\Delta v_{1 / 2}\left(\mathrm{~cm}^{-1}\right) \\
\text { (calc.) }\end{array}$ & 5802 & 5020 & 4976 & 4845 & 4813 & 4805 & 4842 \\
\hline $\begin{array}{c}\Delta v_{1 / 2}\left(\mathrm{~cm}^{-1}\right) \\
\quad(\text { expt. })\end{array}$ & 5900 & 5400 & 5200 & 5100 & 5000 & 5770 & 5677 \\
\hline$\alpha^{2}$ & 0.0118 & $0 \cdot 01138$ & $0 \cdot 0041$ & 0.004 & 0.0026 & 0.0016 & 0.0011 \\
\hline$H_{\mathrm{AB}}$ & 1580 & 1164 & 683 & 640 & 513 & 400 & 300 \\
\hline
\end{tabular}

Table 2. Mixed valence data for the $\left.\left[(\text { edta }) \mathrm{Ru}(\mu-\mathrm{BL}) \mathrm{Fe}(\mathrm{CN})_{5}\right\}^{4-}\right]$ complexes. 


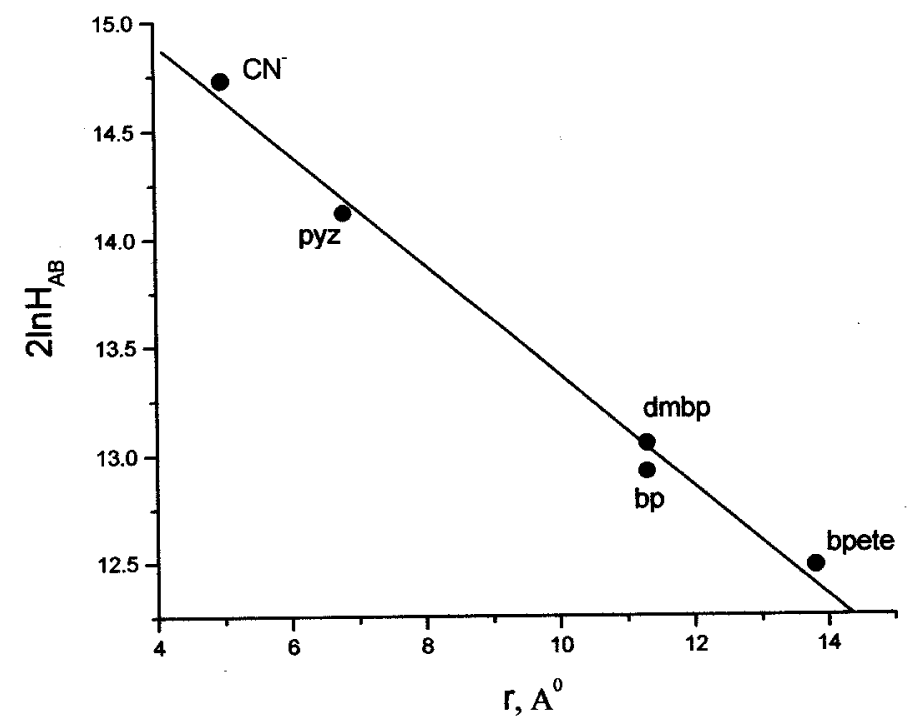

Figure 3. Plot of $2 \ln H_{\mathrm{AB}}$ v $r$ for complexes $\mathbf{I}-\mathbf{V}$.

interaction and hence no IVCT transition band. These two complexes belongs to RobinDay Class I type valence localized system.

\section{Inclusion complexes}

Formation of semirotaxane complexes (IX and $\mathbf{X}$ ) in solution can also be demonstrated by ${ }^{1} \mathrm{H}$ NMR spectroscopy through complexation-induced shift of the resonance signals for the guest molecules (figure 4). Presence of the paramagnetic Ru(III)-centre $\left(d^{5}\right)$ causes an appreciable line broadening and upfield shift of the signals for the protons effect is more prominent for the protons adjacent to the $\mathrm{Ru}(\mathrm{III})-$ centre and limit the possibility of the evaluation of the stability constant of the inclusion complexes, as proposed by Macartney and his coworkers ${ }^{7 e}$. Stability constants for the inclusion complexes bpeta. $\beta-C D, \quad b p p . \beta C D, \quad F e(C N)_{5}$ bpeta. $\beta-C D$ and $\mathrm{Fe}(\mathrm{CN})_{5}$ bpp. $\beta-C D$ are respectively $840,3100,610$ and $1040 \mathrm{M}^{-1} 7 \mathrm{e}$. Moderate values of the stability constant suggest that these inclusion complexes are liable in solution and are present mostly as included ones only in presence of large excess of $\beta-C D$. Electronic spectral and kinetic studies reveal that [2]rotaxane complexes also form in solution by self assembly through the reverse aquation reaction of the pre-synthesized binuclear complexes VI and VII (scheme 1). Further, similar spectral features for XI and XII both in solution and solid state suggest that these complexes remain unchanged in solution. Complexes XI and XII show a characteristics broad absorption band both in aqueous solution and solid state at $\sim 1000 \mathrm{~nm}$ in addition to the bands expected for the individual mononuclear component molecules. As mentioned earlier, the absorption band in the NIR region is not observed for complexes VI and VII as it disappears either on oxidation of Fe(II)-centre or on reduction of $\mathrm{Ru}(\mathrm{III})$-centres and is assigned as an IVCT transition band. Electronic spectral studies reveal that MLCT transition band $\left(d_{\mathrm{Fe}} \rightarrow \pi_{\mathrm{py}} ; 380 \mathrm{~nm}\right.$ for complex XI and $378 \mathrm{~nm}$ for complex $\mathrm{XII})$ for the $(\mathrm{CN})_{5} \mathrm{Fe}^{\mathrm{II}}$-py-core shows a red shift of about $22 \mathrm{~nm}$ 
when compared with that for complexes VI and VII-indicating a lowering of the LUMO-HOMO energy gap of the BL as a result of inclusion. While a very small blue shift is observed for the LMCT band $\left(d_{\mathrm{Ru}} \leftarrow \pi_{\mathrm{py}}\right.$; at $\sim 380 \mathrm{~nm}$ ) for the Ru(edta)-py-centre. Cyclic and differential pulse voltammetric studies show that the $E_{1 / 2}$ values for the $\mathrm{Fe}^{\mathrm{II} / \mathrm{III}}$ couple in both [2] rotaxane complexes has shifted to the anodic side $(<20 \mathrm{mV})$ on inclusion of $\mathrm{BL}$ in $\beta \mathrm{CD}$ cavity - while $E_{1 / 2}$ values for the $\mathrm{Ru}{ }^{\mathrm{II} / \mathrm{III}}$ couple remains almost unchanged. Thus $\Delta E\left(E_{1 / 2}\left(\mathrm{Ru}^{\mathrm{III} / \mathrm{II}}-E_{1 / 2}\left(\mathrm{Fe}^{\mathrm{III} / \mathrm{II}}\right)\right.\right.$ values decrease by only $\sim 15 \mathrm{mV}$ and signifies no appreciable change in potential energy barrier for electron transfer on inclusion of $\mathrm{BL}$ in $\beta \mathrm{CD}$ cavity. Thus electronic spectra and electrochemical studies reveal that inclusion of $\mathrm{BL}$ does not alter the ground state energy of the metal centres. Thus it is reasonable to presume that hydrogen bonding and other non-covalent interactions, which are responsible for the stability of the inclusion complexes, could play a significant role in lowering the energy of the LUMO of the BL without affecting the energy of the $d$-orbitals of the respective metal centres. Thus it seems plausible that for complexes XI and XII, inclusion of BL in $\beta$-CD cavity causes a lowering of the energy of BL to such an extent that the energy of the respective metal orbitals and the LUMO of the BL become similar. This allows the electron transfer to occur between the two metal centres through the $\pi^{*}{ }_{\mathrm{BL}}$ LUMO. A similar explanation was offered for a series of donoracceptor type molecules containing rigid saturated hydrocarbon bridge like dithispiro group, where it was proposed that electron transfer occurs due to the energetic proximity of the HOMO of the donor and acceptor and LUMO of the $\mathrm{BL}^{25}$. Further, apolar interior of the $\beta-C D$ in $\mathbf{X I}$ and $\mathbf{X I I}$ requires less reorganization energy following the optical

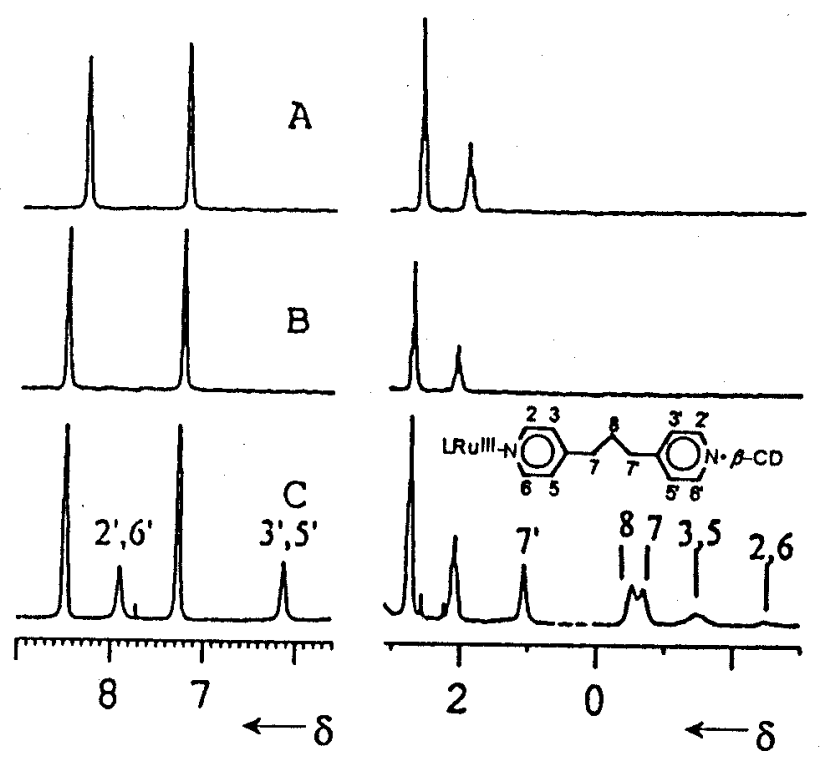

Figure 4. ${ }^{1} \mathrm{H}$ NMR spectra (200 MHz) of bpp in $\mathrm{D}_{2} \mathrm{O}(\mathrm{A})$, (bpp $\left.\bullet-\mathrm{CD}\right)$ and excess $\beta$-CD in $\mathrm{D}_{2} \mathrm{O}$ (B) (LRubpp $\beta$-CD) and excess $\beta$-CD in $\mathrm{D}_{2} \mathrm{O}(\mathrm{C})$; $[\mathrm{bpp}]=2.0 \times 10^{-3} \mathrm{M}$, $[\beta-\mathrm{CD}]=1.6 \times 10^{-2} \mathrm{M}$ and $\left[\operatorname{RuL}\left(\mathrm{H}_{2} \mathrm{O}\right)\right]=6.66 \times 10^{-4} \mathrm{M}$. Spectral features arising from $\beta$-CD protons are excluded for clarity. $p \mathrm{H}$ of the resulting mixture was maintained at $\sim 5 \cdot 0$ using $\mathrm{Na}_{2} \mathrm{HPO}_{4}$. 
electron transfer compared to the solvent water molecules surrounding a non-inclusion complex. Although small, this may have some contribution in lowering the energy of activation for optical electron transfer.

\section{Conclusion}

For a set of mixed valence binuclear complexes where $\mathrm{Ru}^{\mathrm{III}}$ (edta)- and $\mathrm{Fe}^{\mathrm{II}}(\mathrm{CN})_{5}$-centres are linked by conjugated BL, IVCT transition band is observed at $900<\lambda<1000 \mathrm{~nm}$. Energy for optical electron transfer and degree of electronic coupling between the Ru(III) and $\mathrm{Fe}$ (II) centres changes with change in BL. No IVCT transition band and there by no optical electron transfer takes place for complexes where $\mathrm{Ru}(\mathrm{III})$ and $\mathrm{Fe}$ (II) centres are separated by interrupted $\pi$ electron system. However, inclusion of saturated bridging ligand, bpeta/bpp (for complex XI/XII) in $\beta-C D$ cavity has initiated optical electron transfer from $\mathrm{Fe}(\mathrm{II})$ to $\mathrm{Ru}(\mathrm{III})$, which otherwise is not observable in absence of inclusion.

\section{Acknowledgements}

This work was supported by the Department of Science and Technology, New Delhi. Authors thank Dr P K Ghosh for discussion and Dr R V Jasra for his keen interest in this work. ADS thanks the Council of Scientific \& Industrial Research, New Delhi for a fellowship.

\section{References}

1. Crutchley R J 1994 Adv. Inorg. Chem. 41273 and references there in; Ward M D 1995 Chem. Soc. Rev. 34 121; Glockle M, Kaim W and Fiedler J 1998 Organometallics 17 4923; Kaim W, Klein A and Glockle M 2000 Acc. Chem. Res. 33755 and references therein

2. McCleverty J A and Ward M D 1998 Acc. Chem. Res. 31 842; Chen P and Meyer T J 1998 Chem. Rev. 981439

3. Creutz C and Taube H 1969 J. Am. Chem. Soc. 913988

4. Robin M B and Day P 1967 Adv Inorg. Chem. Radiochem. 10 247; Creutz C 1983 Prog. Inorg. Chem. 301

5. Chatterjee D 1998 Coord. Chem. Rev. 168273

6. Lee G-H, Ciana L D and Haim A 1989 J. Amer. Chem. Soc. 1112535

7. Baer A J and Macartney D H 2000 Inorg. Chem. 39 1410; (b) Wylie R S and Macartney D H 1992 J. Am. Chem. Soc. 114 3136; (c) Weddling C A and Macartney D H 1994 Inorg. Chem. 33 5912; (d) Lyon A P and Macartney D H 1997 Inorg. Chem. 36 729; (e) Wylie R S and Macartney D H 1993 Inorg. Chem. 321830

8. Chatterjee D, Bajaj H C and Das A 1993 Inorg. Chem. 324049

9. Chatterjee D, Bajaj H C and Das A 1994 Inorg. Chem. Acta 224189

10. Das A and Bajaj H C 1997 Polyhedron 161023

11. Das A and Bajaj H C 1997 Polyhedron 163851

12. Bajaj H C, Das A and Von Eldik R 1998 J. Chem. Soc., Dalton Trans. 1563

13. Shukla A D, Bajaj H C and Das A 2001 Angew. Chem. Int. Ed. Engl. 40446

14. Smith A C and Macartney D H 1998 J. Org. Chem. 63 9243; Macartney D H 1996 J. Chem. Soc., Perkin Trans. II, 2775; Wylie R S and Macartney D H 1993 Supramol. Chem. 315

15. Das A, Bajaj H C and Chatterjee D 1995 Polyhedron 143585

16. Pseudo first order nature of the reaction for the formation of complex XIand XIIthrough aqua substitution of $\mathrm{Fe}(\mathrm{CN})_{5}\left(\mathrm{H}_{2} \mathrm{O}\right)^{3-}$ by complex $\mathbf{I X}$ and $\mathbf{X}$ respectively (scheme 1) was established by studying kinetics with different $[\{(\text { edta }) \operatorname{RuBL} \bullet \beta-C D\}]^{-}$(where BL is bpete or bpp) keeping $\left[\mathrm{Fe}(\mathrm{CN})_{5}\left(\mathrm{H}_{2} \mathrm{O}\right)^{3-}\right]$ constant. A plot of $k_{\text {obs }}$ vs $\left[\left\{\mathrm{Ru}(\right.\right.$ edta $\left.\left.) \mathrm{BL}^{-}\right\}\right]$gives a straight line with a small intercept, which signifies a reverse aquation reaction. $\left[\left\{(\right.\right.$ edta $\left.\left.) R u B L \cdot \beta-C^{-}\right\}\right]$was varied from 
$6 \cdot 0 \times 10^{-4}$ to $2 \cdot 0 \times 10^{-3} \mathrm{M} ;\left[\mathrm{Fe}(\mathrm{CN})_{5}\left(\mathrm{H}_{2} \mathrm{O}\right)^{3-}\right]=1 \cdot 0 \times 10^{-4} \mathrm{M}, \mu=0 \cdot 1 \mathrm{M}(\mathrm{KCl})$ and $2.0 \times 10^{-3} \mathrm{M}$ $\beta-C D$ (was added to ensure that that (edta)RuBL-species exist only as (edta)RuBL $\bullet \beta-C D$. Pseudo first order conditions using excess of (edta)RuBL $\bullet \beta-C D$ was followed for evaluation of thermodynamic parameters; [(edta)RuBL $\bullet-\mathrm{CD}]=1.0 \times 10^{-3} \mathrm{M},\left[\mathrm{Fe}(\mathrm{CN})_{5}\left(\mathrm{H}_{2} \mathrm{O}\right)^{3-}\right]=$ $1.0 \times 10^{-4} \mathrm{M},[\mu]=0.1 \mathrm{M}(\mathrm{KCl})$ and $[\beta-\mathrm{CD}]=2.0 \times 10^{-3} \mathrm{M}$. Negative $\Delta S^{\#}$ and low $\Delta H^{\#}$ values for this reaction suggest an interchange associative pathway for the substitution reaction.

17. Kinetics of the in situ formation of [2]rotaxane complexes through decomposition of complexes VI and VII were also studied. For these reactions, addition of (edta)RuBL • $\beta-C D$ and/or $\beta$-CD has no effect on observed rate constant; which signifies the dissociation of Fe-Py bond in $\left\{(\text { edta }) \mathrm{Ru}(\mu-\mathrm{BL}) \mathrm{Fe}(\mathrm{CN})_{5}\right\}^{3-}$ is rate determining step. Still excess $\beta-\mathrm{CD}$ was used to ensure complete inclusion of BL in CD cavity. Reaction parameters: $1 \mathrm{ml}$ of $1.0 \times 10^{-3} \mathrm{M}$ [(edta)RuBL], $0.1 \mathrm{ml}$ of $1.0 \times 10^{-4} \mathrm{M} \mathrm{Fe}(\mathrm{CN})_{5}\left(\mathrm{H}_{2} \mathrm{O}\right)^{3-}$ and $0.9 \mathrm{ml} \mathrm{KCl}$ of appropriate concentration (to maintain ionic strength of $0 \cdot 1 \mathrm{M}$ ) were mixed and kept in dark for $15 \mathrm{~m}$ to complete the formation of $\left\{(\text { edta }) \mathrm{Ru}(\mu-\mathrm{BL}) \mathrm{Fe}(\mathrm{CN})_{5}\right\}^{4-}$, then $1 \mathrm{ml}$ of $6 \cdot 0 \times 10^{-3} \mathrm{M} \beta-\mathrm{CD}$ was added and the change in absorbance with time was monitored at $1000 \mathrm{~nm}$. Pseudo-first-order rate constant was found to be independent of the initial concentration of $\{$ (edta) $R u(\mu$ $\left.\mathrm{BL}) \mathrm{Fe}(\mathrm{CN})_{5}\right\}^{4-}\left(\mathrm{BL}=\mathrm{Py}\left(\mathrm{CH}_{2}\right)_{n} \mathrm{Py} ; n=\mathbf{2}\right.$ or $\left.\mathbf{3}\right)$. Furthermore, the observed dissociation rate constant for this reaction is close to that reported for reverse aquation reaction of complex (edta) $\mathrm{Ru}(\mu$-bpp $) \mathrm{Fe}(\mathrm{CN})_{5}{ }^{4-}$.

Inclusion of heterocyclic spacer group BL in (edta)RuBL by $\beta$-CD and formation of [2] rotaxane by reaction of $\{(\mathrm{edta}) \mathrm{RuBL} \bullet \beta-\mathrm{CD}\}^{-}$with $\mathrm{Fe}(\mathrm{CN})_{5}\left(\mathrm{H}_{2} \mathrm{O}\right)^{3-}$ is much faster than the reverse aquation reaction of $\mathrm{Py}-\mathrm{Fe}(\mathrm{CN})_{5}^{3-}$ centre. Activation parameters for this reaction (table 1) also confirm this presumption. Near zero or small $\Delta S^{\#}$ value for this reaction suggests a dissociative pathway

18. On addition of excess DMSO in solution of complex XI or XII, a decrease in absorbance with time at $1000 \mathrm{~nm}$ was registered. Kinetics of decomposition of [2] rotaxane (complexes XIand XII) at $1000 \mathrm{~nm}$ in presence of excess DMSO and $\beta-C D$ is studied. Reaction parameters: $\left[\left\{(\text { edta }) \mathrm{Ru}(\mu-\mathrm{BL} \bullet \beta-\mathrm{CD}) \mathrm{Fe}(\mathrm{CN})_{5}\right\}^{4-}\right]($ complex $\mathbf{X I}$ or $\mathbf{X I I})=1 \cdot 0 \times 10^{-4} \mathrm{M} ;[\mathrm{DMSO}]=0.2 \mathrm{M}$ and $\mu=0 \cdot 1 \mathrm{M}(\mathrm{KCl})$. The observed first order dissociation constant and activation parameters are summarized in table $1 .\left[\mathrm{Fe}(\mathrm{CN})_{5}\left(\mathrm{H}_{2} \mathrm{O}\right)\right]^{3-}$ species produced by dissociation of complex $\mathbf{X I}$ or XII reacts with DMSO to form a kinetically inert complex $\left[\mathrm{Fe}(\mathrm{CN})_{5} \mathrm{DMSO}\right]^{3-}$ and thereby quenches the further possibility of binuclear complex formation. High $\Delta H^{\#}$ and small positive $\Delta S^{\#}$ values for this reaction are indicative of the dissociative pathway. $k_{d}^{\text {dmso }}$, observed dissociation rate constants for XI and XII in presence of DMSO, decreases significantly upon inclusion of ligand in $\beta$-CD cavity (table 1 ). This further demonstrates that $\beta$-CD inclusion of the BL enhances the stability of binuclear complexes

19. Das A, Shukla A D and Bajaj H C 2000 J. Indian Chem. Soc. 7751

20. Hush N H 1985 Coord. Chem. Rev. 64135

21. Elliott C M, Derr D L, Matyushov D V and Newton M D 1998 J. Am. Chem. Soc. 12011714

22. Woitellier S, Launay J P and Spanglar C W 1989 Inorg. Chem. 28 758; Reimers J R and Hush N H 1990 Inorg. Chem. 29 3686; 199029 4510; Larson S 1982 Chem. Phys. Lett. 40 1363; Elliott C M, Derr D L, Matyushov D V and Newton M D 1998 J. Am. Chem. Soc. 12011714

23. Pfennig B W, Cohen J L, Sosnowski I, Novotny N M and Ho D M 1999 Inorg. Chem. 38606

24. Goldsby K A and Meyer T J 1984 Inorg. Chem. 233002

25. Siddarth P and Marcus R A 1990 J. Phys. Chem. 942985 